\title{
NO AGENCIAMENTO TEM DE TUDO
}

\section{Fellipe Eloy Teixeira Albuquerque ${ }^{1}$}

RECEBIDO EM: 16/01/2017 / ACEITO EM: 05/04/2017

$\mathrm{Na}$ escola o professor ensina

Arte de acordo com as disciplinas

O estudante aprende, se desenvolve

As vezes fica contente

Foi com uma moça bonita

Que em 2016 aprendi algo

$\mathrm{Na}$ aula de arte me surpreendeu

No trabalho individual que me devolveu

A proposta era de um alfabeto

Alfabeto de pixo

Descontração, exercício

Sem muito enrosco, o negócio ficou "muito loko"

Disso surge o convite

Me leva pra pixar contigo!

Tá, mas eu não pixo

Acho que graffito...

Pista de Skate, UNIFESP, e outros muros

Foi na Agenda PFC que deu certo

De unir nossos trabalhos, tudo junto

Efeitos, estêncil e bomb com defeitos

Na névoa um ET Brisado

Completa o R-Rodolfo

Da sensibilidade, um pulo

Pra o capricho

Vejo no muro, não um muro

Mas um agenciamento de pixo

Grapixo

Tem imagem tem texto tem de tudo...

1 Mestrando em História da Arte pelo PPGHA- UNIFESP Campus Guarulhos. Licenciado em Educação Artística pelo CEUNSP- Itu. Professor de Educação Básica II- Arte, pela Secretária da Educação do Estado de São Paulo. 
Tem que gosta, quem não gosta

Quem faz pose

Quem acha inútil

Quem patrocina

A vizinhança adere, cede muro

Comenta no Facebook,

Compartilha vídeo

Agradece ao vivo

Nesse muro tem de tudo

Tem caveira, tem movimento

Tem flores, tem lamentos

Tem Zumbi Vive, "tem escorrimentos"

Na Agenda PFC

Só não tem espaço

Para o preconceito...

Respeito

Mais tolerância, por favor!

Sem Racismo, Homofobia e

Machismo

A moça vomita coração

O Bruno é Brunett...

Zé Ninguém, Somos Somados

Panda, Peppa e Neto

Até Corvo tem lugar garantido

No faça você mesmo, meu querido...

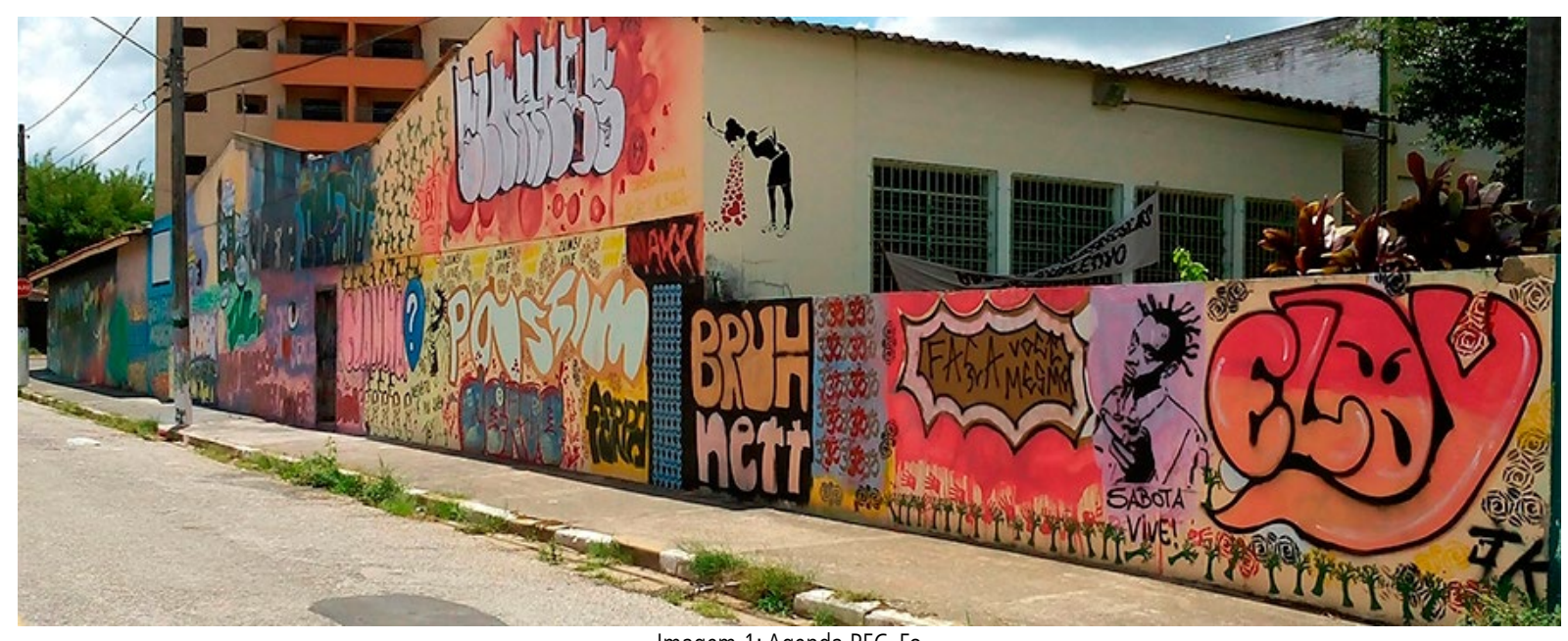

Imagem 1: Agenda PFC. Fo 